\title{
Mistakes as Shadow Capital in Human Ventures
}

\author{
http://dx.doi.org/10.3991/ijac.v7i4.4233 \\ Adamantios Koumpis \\ Universität Passau, Passau, Germany
}

\begin{abstract}
In the paper we present different approaches related to the conceptualisation of mistakes from the literature and situate them with a given methodological framework by Bourdieu. We also draw analogies with the notion of shadow capital and the relevance of applying reflexive learning as a practical means to deal with mistakes in the corporate environment.
\end{abstract}

Index Terms-mistakes, shadow capital, reflexive learning, trust

\section{INTRODUCTION}

\section{A. Context of mistakes}

In [1] we wrote that mistakes are invaluable as they form the shadow capital of any individual or company or organization, supporting the idea of fostering a culture that supports people in recognizing their mistakes and keeping an open accounting process to continuously assess and valuate them according to the original context that enabled their conduct, as well as later interpretations that may either signify an increase of the relative importance of a particular mistake, or a respective decrease. We also presented supporting arguments that mistakes can be treated as other corporate assets that are subject of documentation and reporting. In this regard, an accounting of (or alternatively: for) mistakes can prove useful as it will help justify people's decisions and the rationale underneath.

Bourdieu [2] wonders whether economism [sic] had been able to reduce everything to economics because 'economics deals only with practices that have narrowly economic interest as their principle and only with goods that are directly and immediately convertible into money (which makes them quantifiable)' and concludes that 'as everyone knows, priceless things have their price, and the extreme difficulty of converting certain practices and certain objects into money is only due to the fact that this conversion is refused in the very intention that produces them, which is nothing other than the denial (Verneinung) of the economy'. What can be the relative price of mistakes that appear or happen as results of any human venture? And how can they be valuated against their real monetary value either as a growth capital or as a loss capital for a human venture? In the scope of this paper, we define as human venture any form of human activity of entrepreneurial or business nature related either to a startup or the management of an already established entity.

\section{B. The concept of shadow capital}

The concept of shadow capital is same as this of shadow banking not an official term in the business or finance literature. Looking to the concept of shadow banking may actually offer some advantages in better understanding the concept of shadow capital. The former symbolizes one of the many failings of the financial system leading up to the global crisis. The term shadow bank was coined by economist Paul McCulley [3] and had originally a distinctly U.S. focus and referred mainly to nonbank financial institutions that engaged in what economists call maturity transformation and when commercial banks use deposits, which are normally short term, to fund loans that are longer term. Shadow banks do something similar: they raise (that is, mostly borrow) short-term funds in the money markets and use those funds to buy assets with longerterm maturities. But because they are not subject to traditional bank regulation, they cannot (as banks can) borrow in an emergency from the Federal Reserve (the U.S. central bank) and do not have traditional depositors whose funds are covered by insurance; they are in the 'shadows'.

Something similar happens with our mistakes: if appropriately employed, mistakes can 'finance' our future development and growth - but only if appropriately managed in terms of supporting our learning curves. In [1] we refer to the role of learning from mistakes and how this results in an increase of corporate value. In this paper, our aim is to demonstrate the universal role and presence of mistakes as a living though shadow capital in almost all aspects of human activity and ventures.

\section{FIND GREATNESS IN Mistakes}

Mistakes are like abandoned children - like our very own abandoned children. It is tough to try and look deep into the eyes of our mistakes. How do good companies, mediocre companies, even bad companies achieve enduring greatness. In [4] Eggers and Macmillan recognize that during the past decade, multi-billion-dollar markets have been forming around the world's toughest problems and governments, businesses, and ordinary citizens found out that working together to solve societal issues can be profitable and make a difference by means of a convergence of the public and private sector known as the 'solution economy', and the people, technologies, and business models that have facilitated its growth.

However, next to this solution economy we can see the dystopia of phenomena like burying head in the sand that seems natural for managers who are addicted to good news and trained to success stories ignoring the fact that traditional, data-driven problem-solving methods often fail to achieve results because they are founded on imperfect models of human behaviour. Instead, the tools from human sciences, such as philosophy, sociology, anthropology, and psychology, can provide a better method of comprehending challenges that involve behaviour. Great managers are those who first effectively manage themselves. Self-awareness, introspection, and thoughtful planning and action in all aspects of life are what enable a manager to effectively lead others. However, the idea of inviting managers to take a critical 'look in the mirror' in 
their quests for professional success and personal fulfillment is not uncommon at all as only then can managers take deliberate steps to manage their lives to maximize their talents, make contributions in everything they do, and become inspirational leaders and better human beings.

In an increasingly complex, rapidly changing business environment, corporate directors are playing a far more active role than in the past. Traditionally, boards did little more than monitor; but today, they are partnering with management to take on major strategic - and sometimes executional-responsibilities. In [5] there is plenty of reference material on how boards can most effectively use their power to help their companies maximize opportunities and minimize risk.

However, same as there is an obsession with the CEO as a rainmaker who brings in new business and wins new accounts almost by 'magic', the authors in [6] argue that the 'smartest guy in the room' is not more intelligent than the collective wisdom of a company's entire workforce. However, most business organizations still tend to assign all decision-making responsibilities to one visionary founder, powerful CEO, or senior executive - and together with them they also assign both their expectations for unending successes and, as one may expect, the accountability for any types of possible mistakes. The aforementioned authors also present a set of uses case studies and real business scenarios are presented that illustrate how internal prediction markets make it possible to aggregate the information, insights, and instincts of employee 'investors' from every level of an enterprise.

Jean-René Fourtou is attributed the idea that le vide (emptiness - or what Ronald Burt in his notable research on social networks and social capital, calls 'structural holes' - see [7]) has a huge function in organizations. Though at the time that Burt introduced his theory in [8], social networks were not part of our daily reality and routine life as it is the case now, there is still no identified connection between the concept of a mistake with this of a structural hole. However mistakes form a certain type of such a structural hole in terms that they can be regarded as a 'correlate of organizational learning, often discussed in terms of ability to learn' as Burt defines them in [9].

For many years after leaving my first job, I was proud for avoiding many mistakes that my ex-boss was making. I was deeply (and as it now seems also blindly...) confident that I was better than him as I started my new career under a new employer using as my seed capital the mistakes of my previous boss. Sometime after I bitterly had to recognise that:

a. I had sticked to a small set of easy-to-spot behavioural repertoire patterns that I was (falsely as it is now evident) regarding as mistakes.

b. I had from some point on reproducing the same patterns - so even worse: I was making similar if not the same mistakes while the most important failure was rather that

c. I had regrettably disabled myself from any type of hands-on learning.

So it took some good amount of time till I had overcome my bias in the way I was (and still am) decoding events and creating pictures of what constitutes a mistake both at large and at small scale - in the short run and in the longer run. About twenty years after, and monitoring other people's behavior, I am more convinced that same as me many other people in all different levels of organizational pyramids and almost all stages of their life and career face the same problems: the idea of having made mistakes is not providing them with any type of comfort. And the moral imperative to repair any of them is something that increases their stress levels though it should be very natural and normal. Again we prefer burying head in the sand, shifting the blame to someone or something else or in some extreme cases even annihilating our life than admitting a mistake.

\section{AcCOUnting With Mistakes}

\section{A. Ontological concerns}

In [10], the author draws upon his personal participation in the consulting industry, and describes how the insecure, flexible and transitory nature of consulting work can lead to 'ontological instability' and 'angst' for many consultants which may result in a self-perpetuating cycle of disrespect and dehumanization with those they encounter. Though the article focuses only on the group of management consultants it is not difficult to extend the potential applicability to other groups like teachers, nurses, medical doctors, soldiers, parents, coaches and almost any type of profession.

Interestingly, O'Mahoney in [10] uses an analogy from religion, mentioning that in the popular literature the consultant is often caricatured as either a saint (providing intervention in ameliorating organisational woes) or a sinner (deploying rhetoric to trick managers into paying extortionate fees). In [1] we also mention that as far as the Christian West is concerned, it is worth to examine the role of Christianity, its dogmas and influence on the practices we developed with respect to the learning process and how much it is to be accounted for our tendency to leave out the role of mistakes from it. Religion offers us with a powerful metaphor namely this of the burning bush: an object that according to the narrative was on fire, but was not consumed by the flames, hence the name [11]. As a powerful religious symbol, the burning bush represents many things such as God's miraculous energy, sacred light, illumination, and the burning heart of purity, love and clarity. From a human standpoint, it also represents Moses' reverence and fear before the divine presence.

But while the burning bush is not consumed by its flames, humans unfortunately do: burnout is a particular reaction to stress, a coping mechanism involving emotional exhaustion, depersonalization of those whom one serves, and psychological disengagement from the job [12]. Same as in [12] the authors use the term 'depersonalization', O'Mahoney in [10] uses the term dehumanization to illustrate the manner in which the destruction of trust at a personal level leads to 'ontological insecurity' resulting to the experience of angst at an individual level. O'Mahoney demonstrates the destruction of trust and ontological insecurity is created thus both destabilising and dehumanizing many management consultants through four related themes:

a. the ways in which 'flexible' working practices destroy routine,

b. that incomplete forms of learning led to uncertainty and stress, 


\section{SHORT PAPER \\ Mistakes as Shadow Capital in Human Ventures}

c. that performative ideals resulted in low-trust relationships between consultants, clients and employers, and, finally,

d. that their experiences leads many consultants to distance themselves from the human and emotional aspects of their jobs.

For each of them we can see a potential link with the corresponding concepts of Bourdieu's, as shown in the Table below.

TABLE I.

RELEVANCE OF MistAKES TO THE FOUR THEMES FOR DESTRUCTION OF TRUST AS PER O’MAHONEY [10]

\begin{tabular}{|c|l|l|}
\hline $\boldsymbol{N} \boldsymbol{r}$ & \multicolumn{1}{|c|}{ Theme } & $\begin{array}{c}\text { Relevance to Bourdieu's 3 } \\
\text { levels }\end{array}$ \\
\hline 1 & $\begin{array}{l}\text { 'Flexible' working practices } \\
\text { destroy routine }\end{array}$ & Micro level: Disposition \\
\hline 2 & $\begin{array}{l}\text { Incomplete forms of learning lead } \\
\text { to uncertainty and stress }\end{array}$ & Micro level: Capital \\
\hline 3 & $\begin{array}{l}\text { Performative ideals result in low- } \\
\text { trust relationships }\end{array}$ & Meso level: Habitus \\
\hline 4 & $\begin{array}{l}\text { Experiences lead to distance from } \\
\text { the human and emotional aspects } \\
\text { of the job }\end{array}$ & Macro level: The Field \\
\hline
\end{tabular}

O'Mahoney makes also an interesting connection with the existentialist literature where false personas and relationships lead to an experience of 'inauthenticity', an acting out of 'being' that results in one's dislocation from what one is feeling. The same concept of field is one of the arbitrary concepts used by French social scientist Pierre Bourdieu whose work we refer to before in [2]. According to Bourdieu, a field is a setting in which agents and their social positions are located. The position of each particular agent in the field is a result of interaction between the specific rules of the field, agent's habitus and agent's capital (social, economic and cultural). Fields interact with each other, and are hierarchical (most are subordinate to the larger field of power and class relations). Following our line of thought as mentioned before according to which mistakes are like abandoned children that are having no place to live or stay, as their agents want to get rid of them and ideally if there were an option to reverse the time, they may have liked to not have committed them at all.

The use of spatial qualities to a certain type of mistake such as the case of a wrong, immoral or improper act is very well described in Greek language by the term $\alpha \tau o ́ \pi \eta \mu \alpha$. A mistaken behaviour is a behaviour that is denied any location $(\dot{\alpha} \tau o \pi \sigma v)$ so there is no place to accept or accommodate it.

\section{B. Living with mistakes}

In [1] we devoted a section on the use of metaphors as enablers to conceptualise the role of mistakes as part of the corporate learning process. This is what [13] recognizes that Bourdieu's contribution was when he utilised the concepts of capital and dispositions at the individual level, habitus at the meso level, and the field at the macro level of analysis in order to operationalize his realist project of social inquiry, and this project of social inquiry is very much based on this multilayered analysis of organizational phenomena. While his contribution to the epistemological and methodological understanding is extremely important, for the scope of our addressed research it is the adoption of the aforementioned metaphors or conceptual tools pre- sented by Bourdieu that are extremely important and critical in management and organizational research.

Bourdieu in [14] defines symbolic capital as 'any property (any form of capital whether physical, economic, cultural or social) when it is perceived by social agents endowed with categories of perception, which cause them to know it and to recognize it, to give it value'. An example that he brings is helpful in denoting our main postulate on the value and the practical utility of mistakes: the concept of honor in Mediterranean societies, according to [14] is a typical form of symbolic capital which exists only through repute, that is, through the representation that others have of it to the extent that they share a set of beliefs liable to cause them to perceive and appreciate certain patterns of conduct as honorable and dishonorable. This distinction between flawless and flawful behavior is both the root cause and a recurring curse when dealing with an accounting of mistakes: living with your mistakes is not easy at all if the society tends to irrevocably stigmatise you for their conduct.

Drawing on my own experiences as a boss and on a much bigger pool of experiences of being 'bossed' by several bosses, I was able to see that the core problem with mistakes is, as Johnston describes in [15], when we are applying a bad rule about mistakes: 'It may have been a good rule that kept me out of trouble when I was six years old, but it is not a good rule now that I am older. It is time to change the rule. What would be a better one? In reality, what is a mistake?'

Jonhston uses the analogy with learning to ride a bike to demonstrate that mistakes are a first step towards learning. However, this is a harmless and rather comfortable analogy - what can the voice of conscience advise to a commanding officer who sent all his people to death? Is there a learning curve that you can still refer to as an excuse? And while this is quite a dramatic or extreme example, what about a manager who massively laid off hundreds or thousands of his employees to survive a stress test or a shareholder's meeting? Or an academic who has exploited his PhD students for several years to keep steep his publications and citations records? Is it enough for them to plead innocent and escape their responsibilities? Accounting of mistakes can prove an extremely tricky area - same as in financial reporting, accounting is not an end on its own but a means to an end. We live with our mistakes but we don't have to die with them. Finding the courage to change things may seem difficult but the opportunity is big and is there available anytime we decide to seize it!

\section{Use of reflexion as an enabler for management of mistakes}

Greatness has a price called commitment: in a reflexive organisation groups of people examine themselves, their activities, and their organisation, leading to better adaptation to changing circumstances and challenges, to enhancing their service provision as well as their own intellectual and spiritual wellbeing and that of their organisation [16]. When considering an organizational setting, we see reflexive learning as the main mechanism for 'dealing' with mistakes in terms of knowledge sharing and improvement of the internal processes. 'Dealing' may relate to correction of already conducted mistakes, planning to eliminate or control the conditions that helped them take place, control of any damages caused, etc. Reflexion can be studied at four levels: 


\section{SHORT PAPER \\ Mistakes as Shadow Capital In Human Ventures}

(1) What the individual employee thinks about and focuses on concerning mistakes. We shouldn't take it for granted that all people tend to have the same disposition with respect to some event. Ethics and moral values vary and companies and organisations may only partly influence ethical aspects of the individual.

(2) What a team of employees argue about what constitutes a mistake and what needs to be corrected. This second level relates to the collective understanding of a group of people towards a specific event or a certain type of behavior.

(3) What management levels argue about what constitutes a mistake and what needs to be corrected. Management is approached here as a distinct meta-process that watches other corporate processes and plans for change.

(4) What 'users' (e.g. customers) of the corporate services provide as feedback about mistakes. While for many cases customers may react to a certain type of behavior regarding it as mistaken (e.g. the case of a rude hotel staff), certain other mistakes may never be spotted by the customer (e.g. a wrong medical decision by a specialist).

It is easy to see that there is need for the coordination of various forms of reflexion that nowadays may easily take place in a distributed technological environment, helping the company to operate it as an institutional memory of reflexive activities. Creation of such an institutional memory is always a combination of various activities, both formal (organised) and informal ones, whereby we should underline the role of technology as intensifier and structuring agent of learning processes. So we shouldn't allow any space for mistaken expectations regarding the relative position and value of technology as such - the mistakes may only come from the human side as it is always the case...

\section{CONCLUSIONS}

It is our belief that only with a portfolio of diverse empirical cases one can address the overall research questions:

a. How can the knowledge created in the reflexive learning 'gap closing activities' be developed into a collective repertoire of actions and activities that focus on improving the corporate means of 'dealing' with mistakes?

b. How can these processes be sustained over time in order to improve the performance for the whole organizational unit?

Lack of prior knowledge on what may or may not constitute a mistake and the change of point of view and valuation scale by both the person(s) involved in the conduct of a mistake as well as the wider environment may result in what O'Mahoney identifies in [10] as an endemic disease for the consultancy profession is rather apparent in every working environment nowadays: '[consultants] can neither be trusted by their own companies, their clients or their own colleagues, however, in order to function in any way they are forced to trust. This contradiction [...] produces angst which partially explains the high levels of stress and employee turnover in the profession.'
It is easy to see that in such an environment, admitting mistakes is unbearable. However, it is what we learn out of our mistakes and our failures that may drive us into our future successes. I have spent some good time of my professional life next to leaders who were unable to lead because of fear; I was able to see their lack of capacities to deal with the unknown and how they gave effort only in hiding this. They may have stayed in power for years and the only skill they managed to acquire and master to perfection levels was their own survival and the art of blaming others. The quest for authenticity is a challenge that we may all need to learn even if this concerns our mistakes.

\section{REFERENCES}

[1] Koumpis A., Learning from Mistakes Results in Increase of Corporate Value, International Journal of Advanced Corporate Learning (iJAC) Vol 6, No 3 (2013).

[2] Bourdieu, P. (1986) The forms of capital, in J. Richardson (Ed.) Handbook of Theory and Research for the Sociology of Education (New York, Greenwood), 241-258.

[3] McCulley P. (2007) Speech at the annual financial symposium hosted by the Kansas City Federal Reserve Bank in Jackson Hole, Wyoming, reproduced at: McCulley, Paul (2007) Teton Reflections, PIMCO Global Central Bank Focus.

[4] Eggers W. D., Macmillan P. (2013) The Solution Revolution: How Business, Government, and Social Enterprises Are Teaming Up to Solve Society's Toughest Problems, Harvard Business Review Press.

[5] Charan R., Carey D., Useem M. (2014) Boards That Lead, Harvard Business School

[6] Thompson D. N. (2012) Oracles, Harvard Business School

[7] Burt R. S. (2000) The network structure of social capital, Research in Organizational Behavior 22: 345-423. http://dx.doi.org/10.1016/S0191-3085(00)22009-1

[8] Burt R. S. (1995) Structural Holes: The Social Structure of Competition, Harvard University Press

[9] Burt R. S. (2004) Structural Holes and Good Ideas, American $\begin{array}{lllll}\text { Journal of } & \text { Sociology } 110 & \text { (2): } & 349-399 .\end{array}$ http://dx.doi.org/10.1086/421787

[10] O’Mahoney, J. (2007) Disrupting identity: trust and angst in management consulting, in Bolton, $\mathrm{S}$. (Ed.) Searching for the $\mathrm{H}$ in HRM, Sage.

[11] Bible The, King James Version, Exodus 3:4

[12] Maslach, C., \& Jackson, S. E. (1984) Burnout in organizational settings, Applied Social Psychology Annual, 5, 133-153.

[13] Oezbilgin M., Tatli A. (2005) Understanding Bourdieu's Contribution to Organization and Management Studies, Academy of Management Review, Vol. 30, No. 4, 855-877. http://dx.doi.org/10.5465/AMR.2005.18378882

[14] Bourdieu, P. (1998) Practical reason: On the theory of action, Cambridge: Polity Press.

[15] Johnston D. H. (2001) Lessons for Living: Simple Solutions for Life's Problems, Dagali Press.

[16] Cunliffe, A.L., Jun, J. S. (2005) The Need for Reflexivity in Public Administration, Administration \& Society, 27, 255-243.

\section{AUTHOR}

Adamantios Koumpis is Research Fellow at the Universität Passau in the Fakultät für Informatik und Mathematik at the Lehrstuhl für Informatik mit Schwerpunkt Digital Libraries and Web Information Systems. (email: adamantios.koumpis@uni-passau.de).

Submitted 30 October 2014. Published as resubmitted by the author 08 December 2014. 